\author{
Current Research in Agricultural Sciences \\ 2021 Vol. 8, No. 2, pp. 90-96. \\ $\operatorname{ISSN}(e): 2312-6418$ \\ $\operatorname{ISSN}(p): 2313-3716$ \\ DOI: 10.18488 /journal.68.2021.82.90.96 \\ (C) 2021 Conscientia Beam. All Rights Reserved. \\ check for
updates
}

\title{
EFFECT OF BENEFICIAL SOIL MICROBES ON GROWTH AND YIELD OF CELERY IN VOLCANIC SOIL OF WEST JAVA
}

\author{
Reginawanti \\ Hindersah $^{1+}$ \\ Betty Natalie \\ Fitriatin $^{2}$ \\ (iD) Mieke Rochimi \\ Setiawati $^{3}$ \\ (iD) Rara Rahmatika \\ Risanti $^{4}$
}

\author{
${ }^{1,2,3}$ Department of Soil Science, Universitas Padjadjaran Jalan Raya \\ Bandung-Sumedang, Jatinangor, Sumedang Indonesia. \\ 'Email: reginawanti@unpad.ac.id Tel+62811221834. \\ ${ }^{2}$ Email: betty.natalie@unpad.ac.id Tel+6208122387122 \\ ${ }^{s}$ Email: m.setiawati@unpad.ac.id Tel+628122147664. \\ ${ }^{4}$ Fellow researcher in Soil Biology Laboratory, Department of Soil Science, \\ Universitas Padjadjaran Jalan Raya Bandung-Sumedang, Jatinangor, \\ Sumedang, Indonesia. \\ ${ }^{4}$ Email: rara.risanti@gmail.com Tel+6285659290695
}

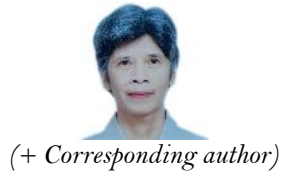

ABSTRACT

Soil beneficial microbes have a critical role in plant growth. Inoculating biofertilizer is suppose essential for supporting the plant performance and hence plant yield. The objective of field experiment was to verify the growth and production of celery (Apium graveolens L.) after biofertilizers application. The experiment had been performed in a plastic house in the mountainous area of tropical volcanic soil of West Java, Indonesia. The field trial was carried out in a Completely Randomized Block Design to test two microbial-coated urea formulas and a mixed biofertilizer. The control treatment was Nitrogen-Phosphorous-Potassium (NPK) compound fertilizer. All treatments were replicated three times. The celery was growing in low Nitrogen but high Phosphor and Potassium soil during the dry season. The field trial verified that plant height and biomass as well as yield of celery didn't depend on fertilizer treatments. Nonetheless, this trial founded that both microbial-coated urea and mixed biofertilizer can replace the NPK fertilizer to produce a same yield of celery.

Contribution/Originality: The study contributes to the existing literatures of biofertilizer application of celery productivity in the tropical mountainous area. The field experiment performed in shading field showed the increase of celery productivity in tropical area under either fertilizer or biofertilizer application.

\section{INTRODUCTION}

Mountainous areas in tropical West Java Province of Indonesia are dominated with volcanic soil where vegetable production is carried out intensively since decades. Low temperature and high organic matter of soil there support the growth of leafy vegetable include celery (Apium graveolens L.). Indonesian people mainly in urban and rural area consume celery as food condiment although celery is not native to Indonesia. The farmer in Bandung Barat Regency of West Java supply large amount of celery every day to the big cities as well as local markets.

In order to meet the market demand, the farmers have to grow new hybrid cultivar of Celery with higher productivity but need higher amount of fertilizer. For plant cultivation in tropical volcanic soil, fertilization is always a must due to low Nitrogen $(\mathrm{N})$ and Phosphate $(\mathrm{P})$ content in soil [1, 2]. Farmers are experiencing intensive inorganic fertilization during plant cultivation to increase the soil chemical fertility. The advantage of inorganic fertilizer are they supply water-soluble nutrient that readily uptake by plant roots; and their nutrients is in accurate 
concentration [3]. Now, detrimental effects of inorganic fertilizer on soil and plant have been recorded. Certain fertilizer composed of impurity i.e. toxic heavy metals that cause soil contamination [4]. The nutrient use efficiency of fertilizer in common are low, less than $20 \%$ and $26 \%$ for Urea and $\mathrm{P}$ fertilizer [5, 6] caused the nutrient accumulation in soil or wash out of root zone and percolate into the ground water. The $\mathrm{N}$ mainly nitrate accumulation in ground water may threaten the quality of drinking water particularly in rural community [7].

Considering the more environmentally friendly agriculture, biofertilizer is recommended to reduce or replace the use of inorganic fertilizers [8]. In general, biofertilizer microbes such as $\mathrm{N}$ fixing bacteria and P-solubilizing microbes also produce phytohormones which is important for cell formation and development, increase growth [9, 10] Phytohormones stimulate and modify plant physiological processes such as respiration, photosynthesis, nucleic acid synthesis and ion absorption [9]. Well known phytohormone-producing microbes in soil are several species of P-bacteria and N-fixing bacteria. Some species of both soil bacterial group enable to produce phytohormone [11, 12]. Leafy vegetable production often use high doses inorganic fertilizers to obtain optimal production. Low $\mathrm{N}$ use efficiency of urea fertilizer [5] cause the residu washed away from the root zone, evaporated to the atmosphere. In order to save inorganic fertilizer, the use of biofertilizer as a source of nutrients and bio stimulants is necessary. Moreover, it is reported elsewhere that biofertilizer inoculation with our without inorganic fertilizer enhanced the yield of celery [13, 14] , but low level chemical fertilizer application followed by biofertilizer decrease the yield [15]. The research team from Soil Biology Laboratory of Soil Science Department, Universitas Padjadjaran have been developed two formulas of soil microbes-based biofertilizer which is Bacillus-Azotobacter solid biofertilizer that coated on urea, and a mixed liquid biofertilizer composing of N-fixing bacteria and P-solubilizing microbes. Both biofertilizer were applied to celery cultivation. The objective of this field experiment was to verify the growth and production of celery plants following addition of microbial-coated urea and mixed biofertilizers.

\section{MATERIAL AND METHODS}

\subsection{Experimental Site}

The experimental field located in Karyawangi village, Parongpong district of Bandung Barat Regency Figure 1 at the altitude of $1260 \mathrm{~m}$ above sea level. The average annual temperature of Parongpong District between JulySeptember 2020 was $17^{\circ} \mathrm{C}-28^{\circ} \mathrm{C}$. Soil in trial field is tropical volcanic soil with slightly acid soil reaction (5.8), organic carbon (C) of $1.62 \%$, and total $\mathrm{N}$ of $0.19 \%$ ). The content of potential $\mathrm{P}_{2} \mathrm{O}_{5}$ and $\mathrm{K}_{2} \mathrm{O}$ were as high as 60.78 $\mathrm{mg} / \mathrm{kg}$ and $44.21 \mathrm{mg} / \mathrm{kg}$ respectively; while avialable $\mathrm{P}_{2} \mathrm{O}_{5}$ was $10.75 \mathrm{mg} / \mathrm{kg}$. The cation exchange capacity (CEC) of soil was as high as $27.58 \mathrm{cmol} / \mathrm{kg}$. In general the soil had limited amount of $\mathrm{C}$ and $\mathrm{N}$, and low ratio of $\mathrm{C}$ to $\mathrm{N}$ but high in $\mathrm{P}_{2} \mathrm{O}_{5}$ and $\mathrm{K}_{2} \mathrm{O}$.

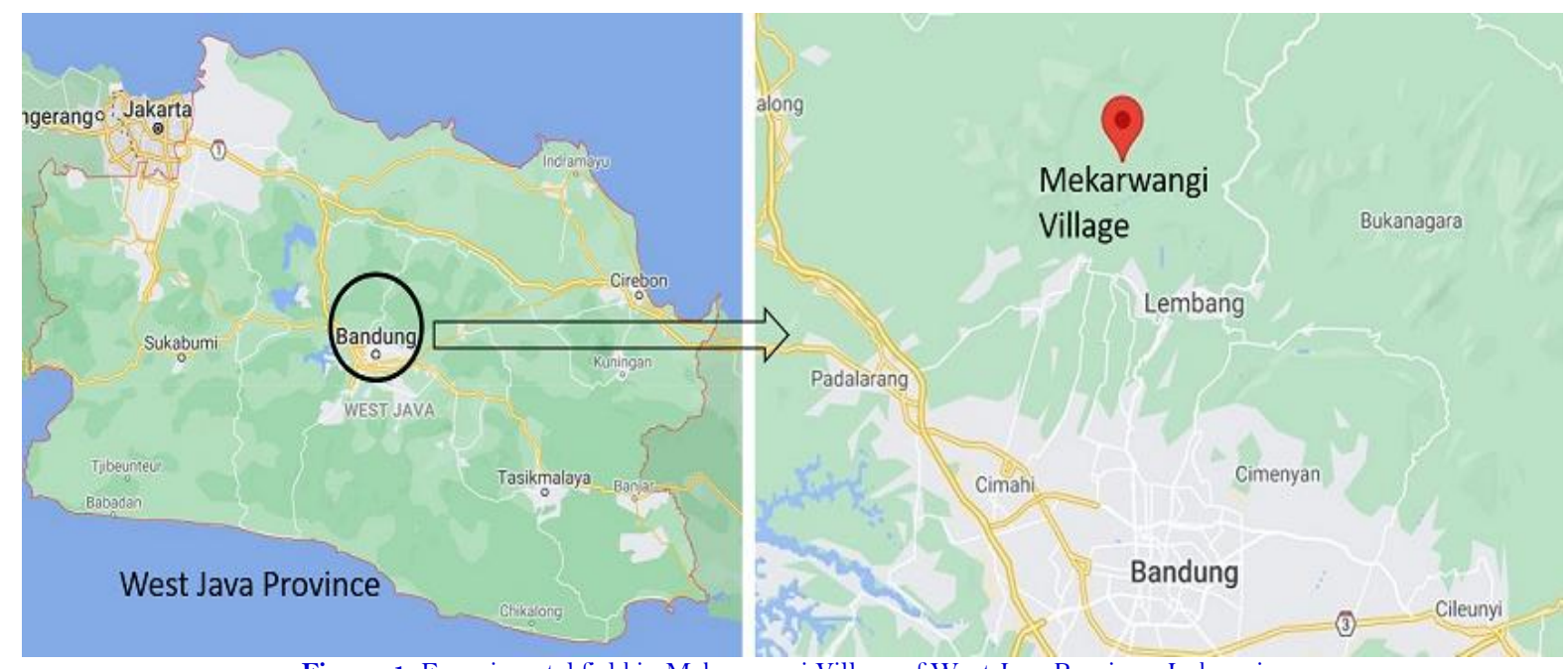

Figure-1. Experimental field in Mekarwangi Village of West Java Province, Indonesia. 


\subsection{Experimental Design}

The experimental design was Completely Randomized Block Design to test three types of biofertilizer and one control treatment, included:
A. Inorganic compound NPK fertilizer (Control).
B. Microbial-coated urea I (MCU I).
C. Microbial-coated urea II (MCU II)
D. Mixed biofertilizer.

Each treatment was replicated 6 times. The MCU formulated by coating prilled urea with solid biofertizer contained two species of Bacillus and another two species of Azotobacter. The solid biofertilizer of MCU I and MCU II were made by $10 \%$ and $5 \%$ of Bacillus-Azotobacter liquid fertilizer respectively. The mixed biofertilizer was formulated in liquid inoculant consist of $\mathrm{N}$-fixing bacteria Azotobacter chroococcum, A. vinelandii, Azospirillum sp. and Acinetobacter sp., P-solubilizing microbes Pseudomonas cepacea and Penicillium sp.

\subsection{Experimental Setup}

The celery cv. Amigo were grown in a plastic house with a bamboo frame and ultraviolet plastic in order to lower light intensity during the day Figure 2. The dimension of each plot in plastic house were $3 \mathrm{~m} \times 1 \mathrm{~m}$ with the distance between plots was $30 \mathrm{~cm}$ Figure 2. Soil in all plots were mixed thoroughly with $20 \mathrm{t} /$ ha cow manure a week before planting. A 17-day old individual celery seedling were planted on $8 \mathrm{~cm}$-depth planting holes with the planting distance of $15-\mathrm{cm}$ between each row and $20-\mathrm{cm}$ between plants in a row.

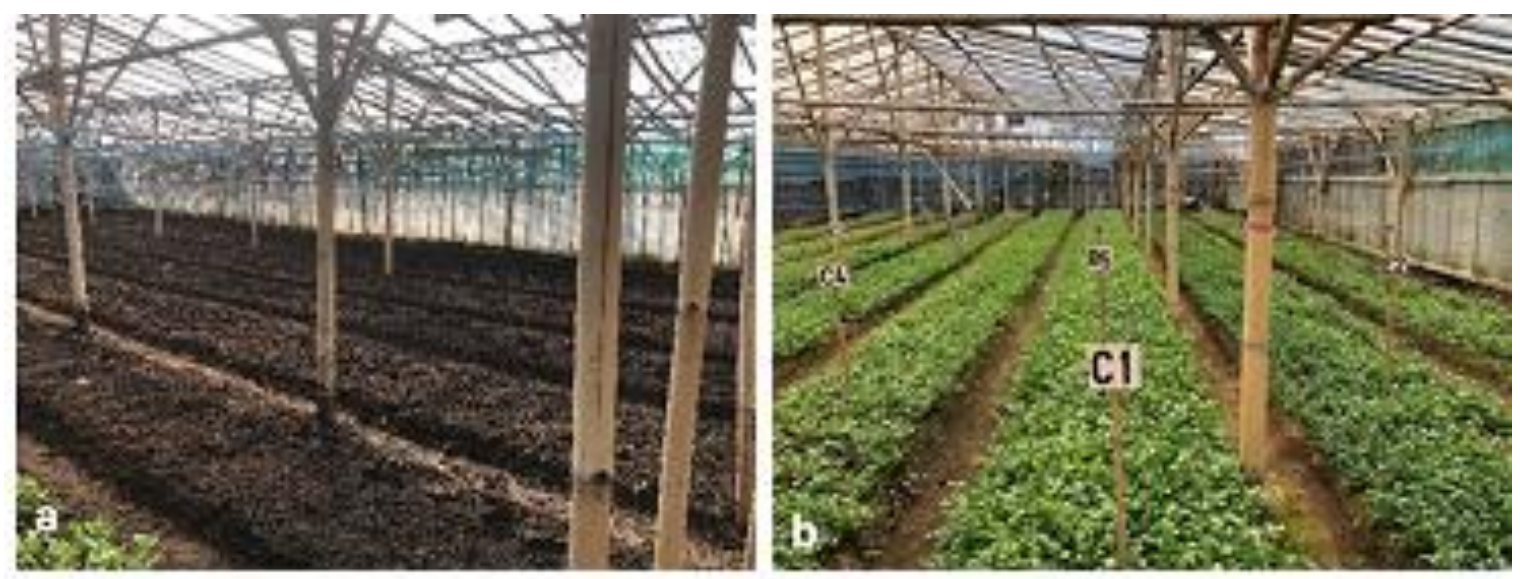

Figure-2. Beds in the field after soil preparation a week before planting (a) and celery grown in pots at 6 weeks after transplanting.

The number of individual plants in each plot were 100. The rate of NPK as a control treatment and MCU fertilizer were $100 \mathrm{~kg} / \mathrm{ha}$ while the dose of liquid mixed biofertilizer was $10 \mathrm{~L} / \mathrm{ha}$. The NPK fertilizer as well as MCU were applied a week before planting by mixing with the soil during bed preparation. The plants were then maintained for 8 weeks at the end of experiment, a whole plant was harvested from six plant sample in each plot Figure 3 .

The shoot height of celery was measured once in two weeks from two weeks after planting until harvest time. At 8 weeks, roots lengths were measured and fresh weight of shoots and roots were weighed. Both of shoots and roots biomass were wrapped in paper bag and stored in the oven for 2 days at $60{ }^{\circ} \mathrm{C}$ until constant weight. The ratio of shoot to root were calculated based on dry weight of shoots and roots. All data exclude celery productivity were subjected to analysis of variance $(\mathrm{p}<0.05)$. If the treatments were significantly affected the parameter, then the Duncan Multiple Range Test was performed. The analysis has been carried out by using software IBM SPSS Statistic version 24 . 


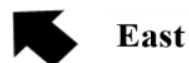

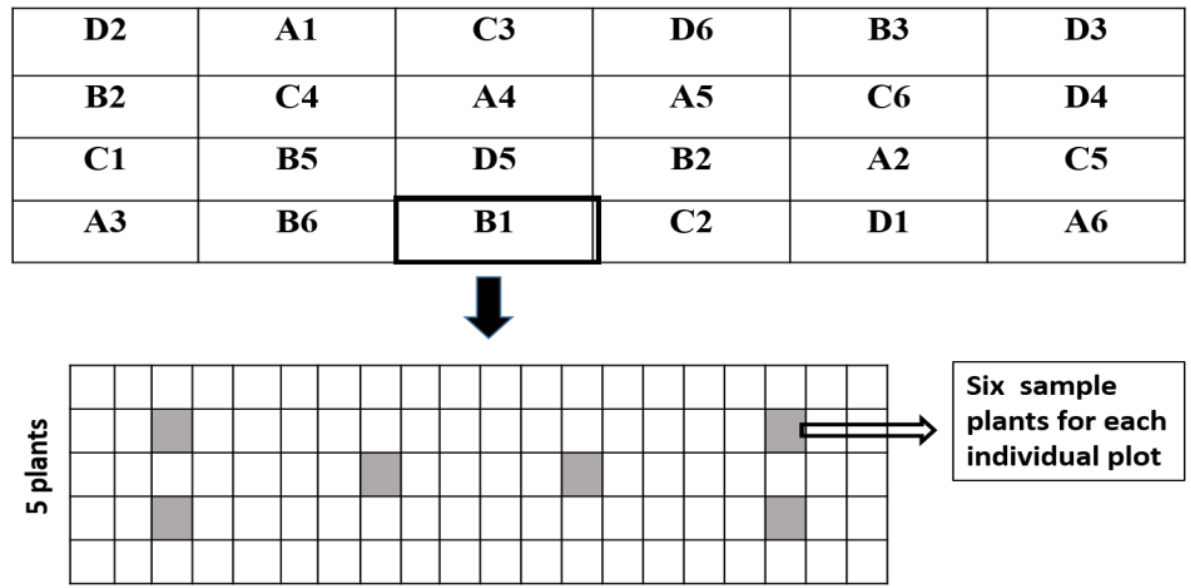

\section{0 plants}

Figure-3. Randomized plot of treatments and sampling plants in each plot of field experiment.

\section{RESULTS AND DISCUSSION}

The analysis of variance verified that the fertilization had no effect on shoot height. At 2-8 weeks after transplanting, the shoot height of celery grown with biofertilizer was similar with control plant Table 1 . There was no different height between three biofertilizer treatments.

Table-1. Shoo height of celery grown with different fertilizer at $2-8$ weeks after transplanting.

\begin{tabular}{|c|c|c|c|c|}
\hline \multirow{2}{*}{ Fertilizer } & \multicolumn{4}{|c|}{ Plant height (cm) at week } \\
\hline & 2 & 4 & 6 & 8 \\
\hline NPK (Control) & $7.6 \mathrm{a}$ & $13.8 \mathrm{a}$ & $20.5 \mathrm{a}$ & $38.1 \mathrm{a}$ \\
\hline MCU I & $7.3 \mathrm{a}$ & $12.9 \mathrm{a}$ & $20.2 \mathrm{a}$ & $35.1 \mathrm{a}$ \\
\hline MCU II & $7.9 \mathrm{a}$ & $14.5 \mathrm{a}$ & $22.6 \mathrm{a}$ & $37.4 \mathrm{a}$ \\
\hline Mixed Biofertilizer & $7.6 \mathrm{a}$ & $15.0 \mathrm{a}$ & $23.9 \mathrm{a}$ & $39.5 \mathrm{a}$ \\
\hline
\end{tabular}

The biofertilizer treatment also have not change the dry weight, shoot to root ratio $(\mathrm{R} / \mathrm{S})$ as well as fresh weight Table 2 and Table 3. It is clearly showed that the $\mathrm{S} / \mathrm{R}$ of any treatments were more than 1, demonstrated that the growth of shoots was exceeded the roots. In this trial, the weight of celery shoot were more than three times greater than roots.

Field experiment resulted in insignificant effect of any biofertilizer treatment of the biomass of fresh shoots and roots Table 3. The fresh weight of shoot is a main celery growth parameter for yield. Harvest time of celery cv. Amigo usually at 90-80 days after harvesting at planting distance 50-70 cm (between rows) and 12-20 (in rows) with the plant productivity about 10-12 t/ha. Many farmers in mountainous area of West Java are narrowing the planting distance to increase plant density and to accelerate harvest time. By adopting this method, the first harvest was at $8-10$ weeks after transplanting.

Table-2. The ratio of shoot to root $(\mathrm{S} / \mathrm{R})$ of celery grown with different fertilizer at harvest time.

\begin{tabular}{c|c|c|c}
\hline \multirow{2}{*}{ Fertilizers } & Dry weight $(\mathbf{g})$ & \multirow{2}{*}{ S/R Ratio } \\
\cline { 2 - 3 } & Shoot & Root & $3.29 \mathrm{a}$ \\
\hline NPK (Control) & $5.52 \mathrm{a}$ & $1.87 \mathrm{a}$ & $4.31 \mathrm{a}$ \\
\hline MCU I & $5.50 \mathrm{a}$ & $1.31 \mathrm{a}$ & $3.81 \mathrm{a}$ \\
\hline MCU II & $6.30 \mathrm{a}$ & $1.89 \mathrm{a}$ & $4.44 \mathrm{a}$ \\
\hline Mixed Biofertilizer & $6.48 \mathrm{a}$ & $1.62 \mathrm{a}$ & \\
\hline Note: Numbers in column followed by the same latter are not significantly different according to Duncan's Multiple Range Test (p $\leq 0.05)$.
\end{tabular}


Table-3. Fresh weight of celery cultivated with different fertilizer at harvest time.

\begin{tabular}{|c|c|c|}
\hline \multirow{2}{*}{ Fertilizer } & \multicolumn{2}{|c|}{ Fresh Weight (g) } \\
\hline & Shoot & Root \\
\hline NPK (Control) & $69.42 \mathrm{a}$ & $6.61 \mathrm{a}$ \\
\hline MCU I & $66.55 \mathrm{a}$ & $6.55 \mathrm{a}$ \\
\hline MCU II & $78.29 \mathrm{a}$ & $7.75 \mathrm{a}$ \\
\hline Mixed Biofertilizer & $78.23 \mathrm{a}$ & $7.55 \mathrm{a}$ \\
\hline
\end{tabular}

The productivity of celery in field with appropriate shading was more than $22 \mathrm{t} /$ ha Table 4 . This surpassed the potential productivity of this cultivar released by seed producer i.e10-12 t/ha. If we suppose that $20 \%$ of a hectare might be utilized for farm utilities, then the productivity of each plots was still exceeding the productivity claimed by the seed producer.

Table-4. Celery yield and productivity cultivated with different fertilizer based on fresh weight of a plot.

\begin{tabular}{c|c|c|c}
\hline & \multicolumn{3}{c}{ Yield } \\
\hline Fertilizers & $\mathbf{k g} / \mathbf{p l o t}$ & ton/ha & (ton/o,8 ha) \\
\hline NPK (Control) & 6.94 & 23.1 & 18.5 \\
\hline MCU I & 6.65 & 22.2 & 17.7 \\
\hline MCU II & 7.82 & 26.1 & 20.9 \\
\hline Mixed Bio-fertilizer & 7.82 & 26.1 & 20.9 \\
\hline Note: MCU: Microbial coated urea.
\end{tabular}

Celery is a sub-tropical vegetable with optimal germination at $9-20{ }^{\circ} \mathrm{C}$, and can still grow optimally at $24{ }^{\circ} \mathrm{C}$. In the tropics, celery grows well in mountainous tropical areas, but the temperature during midday can exceed $24{ }^{\circ} \mathrm{C}$ particularly in the dry season. Shading the celery garden with ultra-violet plastic lowers the sun's intensity and temperature, and hence increase their growth and productivity.

The soil in Mekarwangi Village is used for growing subtropical vegetable throughout the year by using inorganic fertilizer. The high content of $\mathrm{P}$ and $\mathrm{K}$ in soil due to fertilization is evidence. Surprisingly, this field trial verified that the growth and biomass parameter of celery were not depend on fertilization Table 1-3. Celery is leafy vegetable that consume more $\mathrm{N}$ than $\mathrm{P}$ and $\mathrm{K}$ during the vegetative growth. The soil in this experiment was low in $\mathrm{N}(0.19 \%)$. During the cultivation, plants did not show $\mathrm{N}$ deficiency syndrome suppose that in all treatments the available $\mathrm{N}$ in soil was sufficient for celery growth. In control plots, adding $100 \mathrm{~kg} / \mathrm{ha}$ NPK was likely increased the content of available N. Plants grown in plot with MCU uptake the N from urea and N available from N fixation carried out by Bacillus and Azotobacter. In plots treated with mixed biofertilizer, N availability, apart from soil, was supplied by N-fixing bacteria and perhaps P-solubilizing Pseudomonas. Nowadays, researchers have been confirmed that P-solubilizing Bacillus and Pseudomonas enable to fix $\mathrm{N}$ [16]. Low $\mathrm{N}$ in soil induce $\mathrm{N}$ fixation since the nitrogenase enzyme that catalyze the process could not be active in high $\mathrm{N}$ content environment [17].

Plant growth in this field trial was induced not only by sufficient $\mathrm{N}$ in soil but also by the soil $\mathrm{pH}$ of 5.8 ; the optimal soil reaction for celery growth. Increasing soil reaction from 4.5 to 5.5-6.5 clearly enhance the fresh weight of individual plant by about $141 \%$ [18]. The field experiment showed that the yield of celery irrespective of fertilizer treatments was similar based on Duncan's Test. In good cultivation practice, the productivity of celery c.v. Amigo is 10-20 t/ha when plant grow with $70 \mathrm{x} 20 \mathrm{~cm}$ planting distance. The result showed that the productivity was 22.2-26.1 ton/ha Table 4.

The MCU contain $85 \%$ of urea and $15 \%$ of solid biofertilizer although the density of microbes in MCU I was slightly higher compared to MCU II. The celery yield in plots received both MCU was similar to the control plot. This suggested that the use of urea could be reduced and replace it with Bacillus-Azotobacter-coated urea. Coated fertilizer, include urea, release the nutrient slower than conventional fertilizer [10]. Limited information is 
available about the release of $\mathrm{N}$ from microbial-coated urea, but a coated urea fertilizers reduced the ammonia volatilization and increased yield of celery by $14.2 \%-14.9 \%$ [19].

Surprisingly that there was no growth reduction of plants treated with mixed biofertilizer without inorganic fertilizer. The mixed biofertilizer composed of N-Fixing Bacteria and P-Solubilizing Bacteria enabled to produce phytohormones. The positive impact of mixed biofertilizer on plant growth agree with the previous pot experiment of leafy vegetable Brassica rapa L. [6]. However, this trial is the first field experiment of MCU. The addition of all biofertilizer resulted in higher grow of celery shoot than roots; showed that they were not inhibit the shoot growth. Other experiments showed that either solid and liquid biofertilizer had a significant effect on celery yield increment when they mixed with lower dose of inorganic fertilizer [13, 14].

\section{CONCLUSION}

In the field condition with artificial shading, the growth and yield of celery didn't depend on the type of fertilizer. Either NPK fertilizer, microbial-coated urea, and mixed biofertilizer gave the similar plant height, root lengths, root and shoot biomass and ratio of shoot to root. Either inorganic fertilizer and biofertilizer enabled to maintain shoot growth over root, which is support the plant productivity. Regardless the type of fertilizer, the celery productivity in all treatments were higher about 22.2-26.1 t/ha, twice then their potency according to the seed producer. The results showed that for one planting season, the NPK compound fertilizer may be replace by another kind of fertilizer. This field experiment found that biofertilizer has a potency to save the of inorganic fertilizer.

Funding: This research is funded Research and Community Service Directorate of Universitas Padjadjaran.

Competing Interests: The authors declare that they have no competing interests.

Acknowledgement: Author thanks the farmer's community in Mekarwangi for involving in this field trial.

\section{REFERENCES}

[1] S. Sukarman, P. A. Barus, and R. A. Gani, "Soil mineralogy and chemical properties as a basis for establishing nutrient management strategies in volcanic soils of Mount Ceremai," Journal of Degraded and Mining Lands Management vol. 8, pp. 2419-2430, 2020.Available at: https://doi.org/10.15243/jdmlm.2020.081.2419.

[2] T. A. Airlangga, N. Matsue, E. Hanudin, and E. Johan, "Phosphate adsorption capacity of allophane from two volcanic mountains in Indonesia," Journal of Tropical Soils, vol. 25, pp. 39-46, 2020.Available at: https://doi.org/10.5400/jts.2020.v25i1.39-46.

[3] IFA, Fertilizer and their used, 4th ed. Paris France: Internatial Fertilizer Industry Association, 2000.

[4] B. Wei, J. Yu, Z. Cao, M. Meng, L. Yang, and Q. Chen, "The availability and accumulation of heavy metals in greenhouse soils associated with intensive fertilizer application," International Journal of Environmental Research and Public Health, vol. 17, pp. 1-13, 2020.Available at: https://doi.org/10.3390/ijerph 17155359.

[5] A. J. Wallace, R. D. Armstrong, P. R. Grace, C. Scheer, and D. L. Partington, "Nitrogen use efficiency of 15 N urea applied to wheat based on fertiliser timing and use of inhibitors," Nutrient Cycling in Agroecosystems, vol. 116, pp. 41-56, 2020.Available at: https://doi.org/10.1007/s10705-019-10028-x.

[6] T. L. Roberts and A. E. Johnston, "Phosphorus use efficiency and management in agriculture," Resources, Conservation E Recycling, vol. 105, pp. 275-28, 2015.Available at: https://doi.org/10.1016/j.resconrec.2015.09.013.

[7] Y. Gao, G. Yu, C. Luo, and P. Zhou, "Groundwater nitrogen pollution and assessment of its health risks: A case study of a typical village in rural-urban continuum, China," PLoS One, vol. 7, p. e33982, 2012.Available at: https://doi.org/10.1371/journal.pone.0033982

[8] K. M. Rao, P. K. Singh, H. B. Ryingkhun, and B. Maying, "Use of Bio-fertilizers in vegetable production," Indian Hortic Journal, vol. 4, pp. 73-76, 2016. 
[9] S. M. Abbas, "The influence of biostimulants on the growth and on the biochemical composition of vicia faba CV. Giza 3 beans," Romanian Biotechnological Letters, vol. 18, pp. 8061-8068, 2013.

[10] M. Y. Naz and S. A. Sulaiman, "Slow release coating remedy for nitrogen loss from conventional urea: A review," Journal of Controlled Release, vol. 225, pp. 109-120, 2016.Available at: https://doi.org/10.1016/j.jconrel.2016.01.037.

[11] R. Hindersah, M. R. Setiawati, P. Asmiran, and B. N. Fitriatin, "Formulation of Bacillus and Azotobacter consortia in liquid cultures: Preliminary research on microbes-coated urea," International Journal of Agriculture System, vol. 8, pp. 110, 2020.Available at: https://doi.org/10.20956/ijas.v8i1.2283.

[12] A. Saeid, E. Prochownik, and J. Dobrowolska-Iwanek, "Phosphorus solubilization by Bacillus species," Molecules, vol. 23, pp. 1-18, 2018.Available at: https://doi.org/10.3390/molecules23112897.

[13] S. M. Shehata, H. S. Abdel-Azem, A. Abou El-Yazied, and A. M. El-Gizawy, "Interactive effect of mineral nitrogen and biofertilization on the growth, chemical composition and yield of celeriac plant," European Journal of Scientific Research, vol. 47, pp. 248-255, 2010.

[14] W. Yunidawati, R. Riyanti, and M. Mazlina, "The effect of giving bio fertilizer and foliar fertilizer on the growth and yield of celery (Apium graviolens)," Budapest International Research in Exact Sciences, vol. 2, pp. 482-491, 2020.Available at: https://doi.org/10.33258/birex.v2i4.1262.

[15] Z. Ahmed, "Effect of NPK and bio fertilization on growth and oil yield of celery (Apium graveolensL.) and Dill (Anethum graveolens L.) plants," Journal of Plant Production, vol. 8, pp. 247-251, 2017.Available at: https://doi.org/10.21608/jpp.2017.39614.

[16] R. K. Singh, P. Singh, H. B. Li, Q. Q. Song, D. J. Guo, M. K. Solanki, and Y. R. Li, "Diversity of nitrogen-fixing rhizobacteria associated with sugarcane: a comprehensive study of plant-microbe interactions for growth enhancement in Saccharum spp," BMC Plant Biology, vol. 20, pp. 1-21, 2020.Available at: https://doi.org/10.1186/s12870-02002400-9.

[17] S. C. Wagner, "Biological nitrogen fixation," Nature Education Knowledge, vol. 3, p. 15, 2011.

[18] S. Lidar and I. Purnama, "Growth of celery (apium graveolns 1.) In the red-yellow pozolic soils as inoculated bu earthworws pontoscolex corethrurus," Journal Ilm. Pertan, vol. 17, pp. 67-73, 2021.Available at: https://doi.org/10.31849/jip.v17i2.5742.

[19] Y. Xiong, J. Yuan, and R. Hu, "The influence of coated urea on yield and quality of vegetable crops and nitrogen balance in calcareous Chao soil," Journal of Food, Agriculture \& Environment, vol. 8, pp. 655-659, 2010. 